\title{
VIRTUDE, VÍCIO E PECADO NAS OBRAS ÉTICAS DE PEDRO ABELARDO (1079 - 1142)
}

\author{
Pedro Rodolfo Fernandes da Silva \\ Universidade Federal do Amazonas
}

\begin{abstract}
The present article approaches the conception of virtue, vice and sin in the works Dialogus inter philosophum, Iudaeum et Christianum or Collationes and Ethica or Scito te Ipsum, both written by Peter Abelard, which not only contributed for the development of the medieval logic, but also innovated with his ethical research as it distinguished the vice of the sin. Stating the first as an illness of the soul and the second fruit of the consent in the evil which lives in the agent's intention.
\end{abstract}

Keywords: ethics, virtue, vice, sin, intention, consensus.

Resumo: O presente artigo aborda a concepção de virtude, vício e pecado nas obras Dialogus inter philosophum, Iudaeum et Christianum ou Collationes e Ethica ou Scito te Ipsum, ambas escritas por Pedro Abelardo, o qual, além de contribuir para 0 desenvolvimento da lógica medieval, também inovou com sua pesquisa ética à medida que distinguiu o vício do pecado, afirmando ser o primeiro uma enfermidade da alma e o segundo fruto do consentimento no mal o qual reside na intenção do agente.

Palavras-chave: ética, virtude, vício, pecado, intentio, consensus.

\section{À guisa de introdução}

Pedro Abelardo é considerado o maior lógico do século XII, alguém que, glosando a Isagoge de Porfírio, entre outras obras, inseriu uma quarta questão na discussão sobre os universais que se tornou tão clássica quanto o 
eram as três primeiras ${ }^{1}$. Não obstante a contribuição de Abelardo para o desenvolvimento da lógica medieval, interessa-me aqui apresentar a contribuição deste pensador no que diz respeito à ética, área na qual este filósofo tem recebido maior atenção por parte dos pesquisadores nestes últimos anos. Desse modo, tomando as duas obras éticas em questão, principalmente o Scito te Ipsum, apresento em seguida os conceitos fundamentais que constituem o esquema formal da ética filosófica e o tratamento que estes recebem por parte de Abelardo.

\section{Virtude}

O Scito te Ipsum, no qual está a maior parte da reflexão ética de Abelardo, inicia com a definição de vício da alma. Nele, porém, o autor deixa a questão da virtude para o segundo livro, que não chegou até nós. Por esta razão, o recurso ao Dialogus inter philosophum, Iudaeum et Christianum torna-se necessário para se ter uma visão adequada da ética abelardiana, principalmente porque na segunda parte dessa obra, na qual está contido o diálogo entre o filósofo e o cristão, Abelardo discute o problema da virtude e, por intermédio de um dos interlocutores, o filósofo, assim a define:

“O Filósofo: "'Virtude', diga-se, 'é o melhor hábito da alma'. Assim também, reciprocamente, penso que vício é o pior hábito da alma. Aqui chamamos 'hábito' o que o Aristóteles nas Categorias distinguiu quando ele incluiu hábito e disposição nas primeiras espécies de qualidade. Então, um hábito é a qualidade de uma coisa, não implantada naturalmente nela, mas, alcançada por prática e deliberação, torna-se difícil de mudar"”.

Nessa passagem, evidencia-se que Abelardo retoma a definição geral de virtude de Aristóteles com a qual teve contato através da leitura e do

\footnotetext{
${ }^{1}$ Cf. ABAELARD, Die Logica Ingredientibus, Philosophische Scrriften, XII, (1-3): 1-503.

2 Philos. Virtus, inquiunt, est habitus animi optimus, sic e contrario vitium arbitror esse habitum animi pessimum; habitum vero hunc dicimus, quem Aristoteles in Categoriis distinxit, cum in habitu et dispositione primam qualitatis speciem comprehendit. Est igitur habitus qualitas rei non naturaliter insita, sed studio ac deliberatione conquisita et difficile mobilis..." PL 178, col 1651C. Cf. L., p. 128, lin. 19-29.
} 
comentário do livro Categorie, que fazia parte da lógica vetus ${ }^{3}$, visto que as obras éticas do Estagirita não estavam ainda traduzidas e disponíveis nestas alturas do século XII. Por isso, durante "um longo período da história do pensamento, o único meio de conhecer diretamente a moral de Aristóteles se limitava apenas aos escritos lógicos deste filósofo"”.

Abelardo, através do filósofo do Dialogus ${ }^{5}$, atribui a origem da teoria das quatro virtudes a Sócrates, que teria sido o primeiro ou o maior dentre os que enfatizaram o valor do estudo da disciplina moral, e que distinguiu quatro espécies de virtudes: a prudência, a justiça, a fortaleza e a temperança. Afirma ainda que, para alguns, a sabedoria ou a prudência, que é a ciência dos costumes, por sua capacidade de discernir é, mais do que uma virtude individual, a origem das demais e denominada de ciência dos bens e dos males $^{6}$.

De acordo com Pierre Aubenque 7 , a teoria das quatro virtudes sugerida por Platão só se tornaria clássica com os estóicos, pois Aristóteles a ignorou nas éticas. Ao que Platão chamou indiferentemente sofia ou, nas Leis, phronesis, e que designa a sabedoria enquanto conhecimento do inteligível, os estóicos substituirão por phronesis no sentido mais usual da palavra, que designa uma virtude intelectual orientada imediatamente para a ação. Segue observando Aubenque:

"É Cícero que, para traduzir a estóica, recorreu à palavra prudentia (contração de providentia, que evoca a idéia de previdência, de saber eficaz) e é, finalmente, do De officiis de Cícero que Santo Ambrósio (De officiis ministrorum, I, 24,115) e, através dele, toda a Idade Média latina, toma a lista

\footnotetext{
3 O termo logica vetus passou a designar a partir do século XIII, em oposição à logica nova (o restante do Organon redescoberto), um conjunto de textos que incluía os tratados lógicos aristotélicos citados, a Isagoge de Porfírio e, de Boécio, De Syllogismo Categórico, De Syllogismo Hipothetico, De Differentiis Topicis e De Divisione. Cf. Estevão, 1990, p. 101-5. Cf. referências às Categorias em: LUSCOMBE, 1971 , p. 128, nota 3.

4 HAMELIN, 1997, p. 183.

${ }^{5}$ ABÉLARDO, 1995, p. 112.

${ }^{6}$ ABELARDO. Ethics. An edition with introduction, english translation and notes by D. E. Luscombe. Oxford Universsity Press, 1971, p. 128, lin. 8-10. Abreviaremos as citações dessa obra da seguinte maneira: L., p., lin. (Luscombe, a página citada e a linha, quando for o caso).

${ }^{7}$ AUBENQUE, 2003, p.63, nota 9.
} 
das quatro virtudes cardiais (que Santo Ambrósio chama virtutes principales $)^{8}$.

A observação de Aubenque de que Aristóteles ignorou a teoria das quatro virtudes cardeais em seus tratados éticos (a Ética Nicomaquéia e a Eudêmia), e que a Idade Média a recebeu de Cícero através de Santo Ambrósio, é reveladora na medida em que permite concluir que Abelardo recebeu tanto de Aristóteles quanto de Cícero parte de sua concepção ética, com o que parece concordar Guy Hamelin ${ }^{9}$. Aliás, tanto Aristóteles quanto Cícero são citados nominalmente no texto das obras éticas abelardianas ${ }^{10}$.

O sentido aristotélico de , habitus (hábito) é uma qualidade adquirida pelo esforço, que resulta de um constante repetir-se dos mesmos atos; é, portanto,uma constância no agir, que se contrapõe ao impulso irrefletido, e expressa o domínio do agente sobre si mesmo ${ }^{11}$ ".

A concepção de que a virtude é o melhor hábito da alma e também uma disposição prática que concerne à escolha, insere Abelardo no prolongamento da concepção aristotélica de que o ethos - enquanto designa a peculiaridade da vida humana, que se distingue da physis pelo esforço demonstrativo do logos - se constitui como princípio que qualifica os hábitos (hexeis) ou virtudes (aretai) segundo as quais os humanos agem de acordo com sua natureza racional ${ }^{12}$. Assim, a natureza (physis) humana transposta para o mundo da praxis constitui o ethos.

O termo latino habitus foi utilizado por Cícero para traduzir o termo que Aristóteles emprega para designar uma qualidade mais estável e mais constante do que a disposição ${ }^{13}$, que é o segundo elemento deste primeiro gênero de qualidade. Desse modo, infere-se que a virtude moral é uma disposição (prática) relativa à escolha (proairetike), enquanto a prudência, que é uma das virtudes cardeais, é uma disposição prática relativa à regra de escolha ${ }^{14}$.

O caráter de estabilidade e de constância do habitus foi entendido por alguns autores, incluindo Agostinho, como uma 'segunda natureza', provavel-

\footnotetext{
${ }^{8}$ AUBENQUE, 2003, p. 63, nota 09.

${ }^{9}$ HAMELIN, 2004, p. 219-231.

10 Quanto à citação nominal de Aristóteles no Dialogus, cf. nota 225, e no Scito te ipsum, cf. L. p. 128; quanto à citação nominal de Cícero no Scito te ipsum, cf. L., p. 72.

11 Cf. LIMA-VAZ, 2000, p. 14.

12 LIMA-VAZ, 2002, p. 16.

${ }^{13}$ Aristóteles, Categorias, 8b 25-28. In: HAMELIN, 2004, p. 222.

${ }^{14}$ AUBENQUE, 2003, p. 61.
} 
mente sob a influência de Cícero, que embora não tivesse usado tal expressão, deixou-a subentendida ${ }^{15}$.

Não obstante a citação nominal de Aristóteles quando da definição de virtude dada pelo filósofo no Dialogus, há também nesse ponto um profundo eco das concepções agostinianas, até porque o Hiponense é também citado nominalmente ${ }^{16}$. Segundo Silvia Magnavacca ${ }^{17}$, duas são as principais teses agostinianas que o filósofo do diálogo toma como suas na discussão com o cristão: a unidade das virtudes na caridade e a condição desta como "divisor de águas" entre justos e injustos. Quanto à primeira, dizse que em torno da caridade se pode afirmar um lugar comum, no qual é possível buscar a raiz de todas as virtudes para pagãos e cristãos. Quanto à segunda, afirma-se que o amor é a lei.

A concepção abelardiana de virtude parece revestir-se, portanto, de um rigor lógico aristotélico associado a uma concepção cristã do que representa ser a maior virtude: a caridade. A phronêsis aristotélica é, sob certo sentido, superada pela caritas cristã.

Em Aristóteles o reconhecimento do homem de phronêsis, o phronimos, não se dá pela essência, mas pela existência, pois "a existência do prudente, tal como é atestada pela linguagem dos homens, precede a determinação da essência da prudência ${ }^{18 ”}$. Assim, a existência do homem que pratica a caridade atesta a existência da virtude da qual é portador. E o que seria o exercício da maior virtude cristã?

Também nesse aspecto a caridade parecer ser, para Abelardo, como a phronêsis aristotélica, ou seja, exercício que manifesta as intenções dos agentes quando da prática de seus atos. A virtude está na intenção do agente. Diz-se, portanto, virtuoso ou vicioso não o ato em si, mas a intenção com a qual o agente o pratica. Tal parece ser a compreensão da seguinte passagem da Ethica:

"Por isso Santo Agostinho, considerando com diligência, diz reduzindo todo pecado ou proibição antes à caridade ou ao desejo do que à obra: 'A lei nada preceitua a não ser a caridade e nada proíbe, a não ser o desejo'. Donde também o

\footnotetext{
15 HAMELIN, 2004, p.222-3.

${ }^{16}$ Cf. ABELARDO, 1995, p. 106.

${ }^{17}$ MAGNAVACCA, 2000, p. 60-1.

${ }^{18}$ AUBENQUE, 2003, p. 63.
} 
Apóstolo: "Toda lei, diz, completa-se em uma única palavra: “Amarás teu próximo como a ti mesmo" (Rom. XIII 8, 10). E em seguida: "A plenitude da lei é o amor ${ }^{19 "}$

O mesmo entendimento se verifica noutra passagem na qual também cita Santo Agostinho: "Tem a caridade, diz Agostinho, e faze o que queres". ${ }^{20}$

No Scito te ipsum há, de maneira breve, além da caracterização da virtude nos termos já vistos, uma definição de virtude, segundo a qual essa consiste na boa vontade:

"Dirás, porém, talvez que, sendo pecado a vontade da obra má, a qual nos constitui réus perante Deus, como a vontade da obra boa nos faz justos, assim como a virtude consiste na boa vontade, assim o pecado consiste na vontade má e não apenas no "não ser", mas na verdade também no "ser", como aquela 21 ".

Se a virtude é o melhor hábito da alma, que consiste na prática da caridade, o vício é o pior hábito da alma, pois pela sua presença na alma ${ }^{22}$ tornamo-nos propensos a pecar.

\section{Vício da alma (animi vicium) e Pecado (peccatum)}

Da virtude ao vício. Do Dialogus à Ethica. Essa é a passagem que se pode fazer ao analisar a ética abelardiana. Se o tema da virtude é o centro das discussões do Dialogus, não menos verdadeira é a afirmação de que o vício precede as discussões sobre a virtude na Ethica e, como não resta grande

19 "Quod et beatus diligenter considerans Augustinus, omne preceptum uel prohibicionem ad karitatem seu cupiditatem potius quam ad opera reducens ait, 'Nichil precipit lex nisi karitatem et nichil prohibet nisi cupiditatem'. Vnde et Apostolus, 'Omnis lex', inquit, 'in uno sermone competur, diliges proximum tuum sicut te ipsum.' Et rursum, 'Plenitudo legis est dilectio." L., p. 26.

20 "Habe, inquit Augustinus, karitatem, et fac quicquid uis". Agostinho, Epistolam Joannis ad Parthos, Tractatus VII, cap. 8 (PL 35.2033); In: L., p. 38.

${ }^{21}$ Sed fortassis inquies, quia et uoluntas mali operis peccatum est, quae nos apud Deum reos constituit, sicut uoluntas boni operis iustos facit, ut quemadmodum uirtus in bona uoluntate, ita peccatum in mala uoluntate consistat, nec in non esse tantum, uerum etiam in esse sicut et illa". L. p. 06; grifo nosso.

22 "Hoc autem uicium in anima est, ut uidelicet facilis..." L., p. 02. (Grifo nosso) 
coisa das discussões sobre esta (segundo livro da Ethica), pode-se dizer que o ponto central da discussão desta obra é o vício e o pecado ${ }^{23}$.

Seguindo a indicação de Jean Jolivet ${ }^{24}$, para quem o aspecto mais admirável da doutrina ética de Abelardo está formulado nos títulos III, VII e XII do Scito te Ipsum, principiar-se-á pelo terceiro título (Quid sit animi uicium et quid proprie dicatur peccatum), que é o mais extenso, e a partir dele procurar-se-á esclarecer a diferença entre vício da alma e pecado; de modo que essa diferença fundamente a intentio como núcleo da moral abelardiana (final do título III e títulos VII e XII).

Abelardo inicia o terceiro título retomando a discussão anterior sobre a diferença entre pecado e vício. Vício não é pecado e nem este é, por sua vez, ação má. O vício está na alma, ainda que não a leve inexoravelmente à execução da ação: "vício é, assim, tudo aquilo pelo qual nos tornamos propensos a pecar, isto é, inclinamo-nos a consentir no que não convém, de modo a fazê-lo ou evitá-lo25".

Abelardo entende o vício como uma predisposição natural ou uma característica inata do homem, na contramão, portanto, da virtude, que é proveniente de um esforço deliberado que se constitui num hábito da alma. Portanto, possuir o vício, na medida em que este é uma inclinação, não é, por si mesmo, pecado; antes, constitui-se em matéria de luta que uma vez subjugada, e não extinta, trará a glória.

O vício se apresenta, pois, como uma potência da alma humana que pode ou não ser atualizada. Possuir o vício da irascibilidade ${ }^{26}$, por exemplo, não é o mesmo que agir de modo irascível, pois que esse agir pode e deve ser refreado.

Depois de definido o vício da alma, Abelardo define o pecado:

\footnotetext{
${ }^{23}$ Cf. LUSCOMBE, 1971, p. 128, lin 1-7. A citação do Salmo 36,27 "evita o mal e faz o bem" expressa 0 que será posteriormente denominado o primeiro princípio da ordem prática, paralelo ao primeiro princípio da ordem teórica, o princípio de não contradição (Cf. TOMÁS DE AQUINO, Suma Teológica, Ila Ilae. q. 47, a.6)

24 JOLIVET, 1997, p. 93.

25 "Vitium itaque est quo ad peccandum proni efficimur, hoc est, inclinamur ad consentiendum ei quod non conuenit, ut illud scilicet faciamus aut dimittamus". L., p. 04.

${ }^{26}$ Segundo Mann, Abelardo parece considerar a irascibilidade e a luxúria como vícios próprios da constituição corporal humana que dever-se-ia aprender como controlar. Eles são distintos de outros vícios, como a ganância e a glutonaria, que são adquiridos através de escolhas pecaminosas. MANN, 2004, p. 302.
} 
"A esse consentimento [ao que não convém] chamamos propriamente pecado, isto é, culpa da alma, pela qual ela merece a condenação ou é determinada como ré perante Deus. O que é, com efeito, esse consentimento senão desprezo de Deus e ofensa a ele? De fato, Deus não pode ofender-se por dano, mas pelo desprezo. Ele é aquele sumo poder que não se diminui por algum dano, mas se vinga do desprezo de si. Nosso pecado é, assim, o desprezo do Criador e pecar é desprezar o criador, isto é, não fazer, de modo algum, por causa dele, aquilo que cremos dever ser feito por nós por causa dele; ou não evitar por causa dele o que cremos dever ser evitado 27 ".

O pecado, em sentido próprio, é o consentimento (consensus) que é de fato desprezo de Deus (contemptus Dei) e ofensa (offensa) a ele por não fazer o que cremos dever fazer por causa dele e não evitar por ele o que cremos dever evitar. Acresce que Deus não pode ser ofendido por dano, mas por desprezo (contemptus), pois ele é o sumo poder.

Marenbon ${ }^{28}$ afirma que Abelardo entende o pecado como um ato interior, precedendo o ato externo ou, no caso em que o ato externo não é concretizado, permanece nesse sentido primeiro, ou seja, enquanto consentimento.

Portanto, todos os pecados são atos de consentimento ou adesão a algo, mas nem todos os atos de consentimento são pecados. O que torna um ato de consentimento pecado é o fato de que se constitui num desprezo e numa ofensa a Deus. Assim, Abelardo deixa explícito que ninguém e nada pode prejudicar de Deus ou causar-lhe dano, mas pode desprezá-lo ou ofendê-lo.

Segundo $\mathrm{Mann}^{29}$, a definição de desprezo de Deus apresentada por Abelardo (não fazer por causa dele o que se acredita dever ser feito, ou não

\footnotetext{
27 "Hunc uero consensum [ei qudo non convenit] proprie peccatum nominamus, hoc est, culpam animae qua dampnationem meretur, uel apud deum rea statuitur.Quid est enim iste consensus nisi Dei contemptus et offensa ipsius? Non enim Deus ex dampno sed ex cotemptu offendi potest. Ipse quippe est summa illa potestas que dampno aliquo non minuitur, sed contemptum sui ulciscitur. Peccatum itaque nostrum contemptus creatoris est, et peccare est creatorem contempnere, hoc est, id nequaquam facere propter ipsum quod credimus propter ipsum a nobis esse faciendum, vel non dimittere propter ipsum quod credimus esse dimittendum." L., p. 04, lin. 29-33; p. 06, lin. 1-6.

${ }^{28}$ MARENBON, 1997, p. 258.

29 MANN, 2004, p. 290.
} 
omitir por causa dele o que se acredita dever ser omitido) desdobra-se em dois tipos de faltas: 1) não fazer aquilo que a pessoa acredita que deveria ter sido feito, e 2) não refrear aquilo que se acredita deveria ter sido contido. Abelardo discute o primeiro tipo de falta na Ethica, cujo exemplo principal é um caso que envolve ignorância não-culpável ${ }^{30}$. O exemplo que ilustra uma falta no refrear é um caso de crença enganosa ${ }^{31}$. Assim sendo, a distinção entre agir na ignorância e agir no erro convicto tenderia a ocupar a atenção de Abelardo mais que a distinção entre não fazer e não conter.

$\mathrm{Na}$ interpretação de R. Blomme ${ }^{32}$ o pecado, como Abelardo o descreve, não necessita ser um desprezo de Deus formal ou expresso, mas um reconhecimento de que o que se faz é oposto à vontade divina. Dito de outro modo, não há necessidade de que se formalize ou expresse algum tipo de desprezo ao criador; basta que conscientemente, porque não há pecado senão contra a consciência ${ }^{33}$, se faça algo contrário à vontade divina, o que é, ipso facto, um desprezo desta, isto é, de Deus.

Luscombe $^{34}$, por sua vez, ressalta que, na Ethica, Abelardo tem pouco a dizer sobre o pecado como não-ser porque está procurando uma definição moral do pecado e uma compreensão psicológica da imputabilidade moral. Portanto, sua consideração situa-se ao contrário da escola de Anselmo de Laon, que se preocupou com a natureza ontológica do pecado e do mal. Mestre Pedro enfatiza apenas que sua definição de pecado nega qualquer substância a este, assim como as trevas são um não-ser em relação à luz:

\footnotetext{
${ }^{30}$ Cf. L., p. 54, lin. 27-33; p. 56, lin. 1-15. Esse exemplo é tomado de Lc 23,34, onde Jesus roga ao Pai que perdoe seus algozes. Abelardo pergunta se os perseguidores de Cristo pecaram no fazer aquilo que acreditavam agradável a Deus, ou, se poderiam deixar de fazer sem pecado o que acreditavam que não se pode deixar de fazer. Dito de outro modo, o exemplo de ignorância não culpável refere-se ao fato de que os algozes de Cristo, uma vez que ignoravam a vontade Deus, não poderiam ser culpabilizados pelos atos que praticaram. Em contrapartida, se não pecaram, por que Jesus roga ao Pai que os perdoe? Disso resulta que Abelardo apresentará quatro definições de pecado. Cf. L., p. 56.

${ }^{31}$ MANN, 2004, p. 294, alerta para o fato de que Abelardo não discute na Ethica e no Dialogus o tipo de falta que resulta no desprezo de Deus por não refrear aquilo que se acredita deveria ter sido contido. No Comentário à Carta de Paulo aos Romanos (306.313-314), Abelardo analisa a passagem escriturística Rm 14, 23, onde São Paulo diz, sobre certos alimentos, que "Quem tem dúvidas e assim mesmo toma o alimento, está condenado, porque ele não age com fé; e tudo o que não procede da fé é pecado" (Romanos 14:23). Abelardo interpreta tal passagem afirmando que "peca mesmo quem usa legalmente coisas contra sua consciência".

32 BLOMME, R. La doctrine du péché, p. 154-8. In: LUSCOMBE, 1971, p. 6, nota 1.

${ }^{33}$ Cf. título XIII: Quod peccatum non est nisi contra conscientiam. L., p. 54. Segundo Dihle (1982, p. 81), para São Paulo, a consciência indica, espontânea e distintamente, se uma ação ou omissão esteve ou estará de acordo com a vontade de Deus.

${ }^{34}$ LUSCOMBE, 1971, p. 7, nota 02.
} 
"Ao definir o pecado negativamente, dizendo, por exemplo, 'não fazer ou não evitar o que convém', mostramos claramente que não há nenhuma substância do pecado - o qual no 'não ser' mais do que no 'ser' subsiste, como se, ao definir as trevas, disséssemos: 'ausência da luz onde houve luz ${ }^{35}$,.”

Para Lottin ${ }^{36}$, o pecado, de acordo com Abelardo, consiste no consentimento (consensus) à vontade humana, quando esta contraria a vontade divina. Em seguida afirma que o conceito de consensus é substituído pelo de intentio ${ }^{37}$ para qualificar os atos externos que são denominados pecados por referência ao consentimento do agente.

De fato, segundo Abelardo, o mesmo ato pode ser feito com intenções distintas, pois, tanto o Pai como o traidor entregou Cristo à morte; isso não quer dizer que a intentio que animava a ambos era a mesma e, portanto, se Judas fez o bem, não o fez de modo bom ${ }^{38}$. O pecado não consiste, então, nem no ato exterior e nem no prazer que lhe é inerente, mas consiste unicamente no consentimento a este ato e a este prazer, caso eles sejam contrários à vontade de Deus. Que o pecado não consiste no ato externo como tal, nem tampouco no prazer que pode proporcionar, é o que se verifica em todos os atos que asseguram a conservação do indivíduo e da espécie. Do contrário, seria necessário condenar os próprios atos, dado que são a causa do prazer; assim, seria necessário condenar também a Deus, que criou o homem com essa inclinação.

$\mathrm{Mann}^{39}$ assinala que Abelardo apresenta três teses negativas sobre o pecado. A primeira consiste em dizer que o pecado não é o vício da alma, pois este último inclina ao mal, mas pode ser refreado de modo a manter a virtude. A segunda consiste em afirmar que o pecado não é a ação má em si mesma, pois é possível alguém praticar uma ação má sem, no entanto, pecar, como no caso de uma ação má praticada por coação física. Por último, a

35 "Cum itaque peccatum diffinimus abnegatiue, dicentes scilicet non facere uel non dimittere quod conuenit, patenter ostendimus nullam esse substantiam peccati quod in non esse potius quam esse subsistat, ueluti si tenebras diffinientes dicamus absentiam lucis ubi lux habuit esse". L., p 06.

${ }^{36}$ LOTTIN, 1954, p.310-2.

${ }^{37} \mathrm{~A}$ primeira vez que o conceito de intentio aparece no texto da Ethica é no final do título III, de acordo com a edição utilizada, na página 28 , linha 11: "in intentione meritum operantis uel laus consistit". A passagem refere-se ao fato de as obras que convém ou não fazer, são igualmente realizadas por homens bons ou maus, distinguidos apenas pela intenção.

${ }^{38}$ Cf. L., p. 28.

39 MANN, 2004, p. 280-1. 
terceira tese consiste em afirmar que o pecado não é a vontade, pois certas vontades humanas não contrariam a divina, donde se pode afirmar que alguém pode ter certa vontade mas nem por isso pecar.

No texto ${ }^{40}$, Abelardo evoca um interlocutor hipotético que afirmaria que o pecado também residiria no ser da vontade má (uoluntas mali) que nos torna réus perante Deus. Ao que Abelardo responde que, às vezes, pecamos sem a vontade má, e que essa, quando refreada, obtém a palma aos que resistem e proporciona matéria de luta e a coroa de glória aos que lutam. Dela deve-se dizer que é, não tanto um pecado, mas muito mais uma enfermidade $^{41}$ (infirmitas) inevitável.

Para explicar que o pecado não é a vontade má, Abelardo exemplifica com o caso de um servo que foge de seu senhor que queria matá-lo $\mathrm{o}^{42}$. Encurralado e temendo pela própria vida, o servo mata o senhor. Acrescenta Mestre Pedro, que o servo querendo fugir da morte quis conservar a própria vida - o que não pode ser chamado de modo algum de vontade má. Mesmo que se quisesse denominar de vontade má, esta que teve ao matar seu senhor, não se poderia fazê-lo, pois o fez sem querer e coagido. Ainda, como poderia fazer voluntariamente aquilo que o expôs ao perigo de vida, isto é, matar o senhor?

Assim, o servo pecou, não por ter agido impelido pela vontade má contra seu senhor, mas porque delinqüiu consentindo, mesmo que coagido pelo medo da injusta morte, no ato de matar que lhe pareceu mais oportuno do que sofrer a morte; por si mesmo, com efeito, tomou a espada.

Como assinala Mann ${ }^{43}$, Abelardo ao usar o caso do servo teria se valido de um exemplo que apareceu no Livro I do De Libero Arbítrio ${ }^{44}$, de Santo Agostinho. O Palatino teria refeito o exemplo para apresentar uma interpretação da própria análise de Agostinho. Refeito, porém, o exemplo, fia-se no aparato conceitual que Agostinho teria desenvolvido depois de escrita a obra. Apesar disso, Agostinho e Abelardo concordam que o criado fez alguma coisa errada e discordam no diagnóstico em que consiste essa injustiça.

\footnotetext{
${ }^{40}$ L., p. 06.

41 Infirmitas remete tanto a enfermidade quanto a fraqueza, o que parece bastante razoável e próximo do que sustenta J. Jolivet (1997, p. 94), isto é, que a vontade má se assemelha ao vício, porquanto ambos são "fraquezas da alma".

42 L., p. 06-8.

${ }^{43}$ Cf. MANN, 2004, p. 282-3.

44 AGOSTINHO, De Libero Arbítrio, I.3.8 - 1.4.10. Disponível em http://www.augustinus.it/libero arbitrio/index2.htm. Na primeira passagem Agostinho recorre a um caso de adultério (o que remete a $\overline{\mathrm{Mt}}$ $5,28)$. Evódio concorda que se dá o mesmo no homicídio, no sacrilégio e em todos os pecados. $\mathrm{Na}$ segunda comparece o caso de um escravo que mata seu senhor por temor de grandes tormentos.
} 
No De Libero Arbitrio, Agostinho investiga a hipótese de que todo delito é motivado por um desejo desordenado (inordinata desiderare ou inordinata libido), que é desproporcional ao valor do que é desejado. O exemplo do escravo que mata seu senhor parece, em princípio, ser um contraexemplo, porque se supõe que o desejo do escravo é viver uma vida sem medo, e ninguém pode ser condenado por ter este desejo. A resolução que Agostinho apresenta para o caso é de reivindicar que o desejo do escravo não é desordenado porque o conduz a superestimar a própria vida que é, certamente, algo bom, assim como é a vida de seu senhor. Mas a vida do escravo não é o tipo de coisa que pode ser possuída sem o medo de perdê-la. Assim, alguém que desejasse possuir a vida sem medo de perdê-la, não importa a que custo, deixaria de considerar que, às vezes, o custo é também elevado, pois, possuir a própria vida, nesse exemplo, implicou perder a vida do outro. Agostinho estaria aqui se referindo à vida terrestre e pressagiando a hierarquia de valores que desenvolveria no II Livro do De Libero Arbítrio.

Talvez o problema esteja no fato de que a hipótese de Agostinho se fixa num jogo de desejos incontroláveis, artimanha que Abelardo não aceita, pois não há nada errado em o servo querer preservar sua vida; nada sugere ao Palatino que este desejo é desordenado. Se não há nada de errado com a vontade de conservar a própria vida, por que o servo queria matar seu senhor? Para Abelardo, o servo não tem tal vontade. Ele matou seu senhor contra sua vontade. ${ }^{45}$

Mann ${ }^{46}$ observa ainda que seria possível criticar Abelardo afirmando que ele está certamente enganado, porque a ação do servo ao matar o senhor não foi uma questão de inadvertência ou acidente, pois é óbvio que o servo quis matar seu senhor e este mesmo desejo foi que o levou a fazê-lo. O servo, apesar de tudo, poderia ter consentido em sua própria morte em lugar de matar o senhor. Que o servo tenha escolhido matar seu senhor, mostra que, mesmo se tivesse um desejo de não matar, esse desejo foi superado pelo desejo de matar. Abelardo dissimula essa possibilidade para reivindicar que o servo matou de má vontade. Mas, considerando que Abelardo concorda que a morte do senhor foi injusta, no que pode, então, consistir o mal em si mesmo se não há um mau desejo?

45 L., p. 08.

${ }^{46}$ MANN, 2004, p. 284. 
Para entender por que a crítica é falha basta ter em conta que, para Abelardo, uma e mesma ação pode ser feita de má vontade, porém, intencionalmente. Uma ação intencional não precisa ser qualquer ação praticada que teve um forte desejo por detrás. Quando, nesse exemplo do servo, Abelardo usa o verbo volo (eu quero) e nolo (eu não quero) ${ }^{47}$, eles se aplicam exclusivamente a desejos. Correspondentemente, quando fala da voluntas (vontade) de um agente, está simplesmente se referindo ao que o agente deveria querer fazer, assumindo que este não esteja sujeito a qualquer espécie de coerção. Em circunstância propícia, o que o agente faz intencionalmente, só é o que o agente deveria querer fazer. Mas nem todas as circunstâncias são propícias.

Abelardo submete o servo ao senhor para ilustrar a possibilidade de um agente que age intencionalmente, mas contrariado. $\mathrm{O}$ mesmo se poderia verificar no seguinte exemplo, no qual o pecado do agente não surge de maneira explícita. $\mathrm{O}$ assaltante que propõe ao assaltado uma escolha entre "seu dinheiro ou sua vida", muito provavelmente induzirá o assaltado a entregar seu dinheiro intencionalmente, mas de má vontade. Nesse caso, a rendição do assaltado e a entrega de seu dinheiro podem ser voluntárias, até mesmo quando executada de má vontade. Mas, nesse caso, "voluntário" pode significar somente que sua ação não foi submetida a uma necessidade inevitável ou que a ação corresponde a um outro desejo seu: o desejo de escapar à morte ou de adiá-la.

Em ambos os casos, do servo homicida e da vítima do assaltante, há algo em comum: são espécimes de ação intencional, de má vontade, em todo caso, ação voluntária. Parece importar a Abelardo a distinção entre desejo e intenção porque ele quer situar a ação má não no desejo, mas na intenção do agente.

$\mathrm{Na}$ seqüência do texto da Ethica, Abelardo trata de distinguir a vontade má (voluntas mala) da paixão (passio). A paixão é algo que se sofre, não como fim último, mas como meio para se atingir um fim. É o que Abelardo quer provar citando vários exemplos; dentre eles o fato de que o enfermo tolera ser queimado ou cortado, tendo em vista a cura, do mesmo modo que os mártires sofrem para chegar a Cristo e o próprio Cristo, para que a humanidade se salvasse pela sua paixão ${ }^{48}$. Do mesmo modo, se alguém diz, "quero que fiques com minha capa para que me dês cinco soldos", é o

${ }^{47}$ L., p. 08.

${ }^{48}$ L. p. 8; 10. 
mesmo que se dissesse que a entrega por esse preço; nem por isso afirmaria que quer que ela fosse de outrem.

Quando se satisfaz a vontade, não há paixão. A paixão é sempre contrária à vontade: "Não pode haver paixão (passio) senão onde se faz algo contra a vontade. Ninguém sofre ou padece naquilo em que sacia sua vontade e faz o que lhe agrada 49 ".

Se é possível afirmar que a vontade é pró-ativa e não coincide com o pecado, é possível igualmente dizer que a paixão é passiva e também, por sua vez, não coincide com o pecado. Nesse sentido, a paixão aproxima-se de uma vontade passiva, algo que se quer ou se aceita ou suporta em vista de outro.

Segue $\mathrm{Abelardo}^{50}$ em diálogo com um hipotético interlocutor, apresentando este o exemplo de alguém que vê uma mulher e cai na concupiscência, ficando sua mente afetada pela deleitação carnal. Disso resulta que é devorado pelas chamas da desordenada possessão carnal. Que é, então, esta vontade e torpe desejo senão pecado?

Mais uma vez Abelardo pretende esclarecer que pecado não é a vontade má, embora essa seja inerente à natureza humana e ocasião de luta. Para que haja luta, é necessário um inimigo que nos enfrente e não um que $\operatorname{logo}$ se rende ${ }^{51}$. Só teria valor o que custa esforço. Neste caso, o homem virtuoso, que pratica os atos virtuosos com facilidade, teria menos mérito do que o principiante que ainda precisa se esforçar para agir bem.

No sobrepujar a vontade má, que é contrária à vontade divina, está o mérito diante de Deus. Ressalte-se que esse mérito, acresce Abelardo, não está, de modo algum, na ação, mas na intenção ${ }^{52}$ :

"Então - dirás tu, o que merecemos junto de Deus, pelas obras que fazemos querendo ou constrangidos? Nada, respondo. Ele pesa, antes o espírito que a ação, em vista da remuneração; nem a ação acrescenta coisa alguma ao mérito, quer venha de uma boa ou de uma má vontade."

\footnotetext{
49 "Nusquam enim passio esse potest nisi ubi contra uoluntantem aliquid fit, nec quisquam in eo patitur ubi suam implet uoluntatem et quod fieri eum oblectat" L., p. 10.

${ }^{50}$ L., p. 10,12 .

51 "Vt uero pugna sit, hostem esse conuenit qui resistat, non qui prorsus deficiat". L., p. 12.

52 "Aut quid, inquies apud Deum meremur ex eo quod uolentes aut inuiti agimus? Nichil certe, respondeo, cum ipse animum potius quam actionem in remuneratione penset, nec quicquam ad meritum actio addat, siue de bona siue de mala uoluntate prodeat..." L., p. 12, lin. 18.
} 
Desse modo fica também estabelecido que o pecado, bem como o mérito diante de Deus, não residem na ação exterior, pois esta é moralmente indiferente. $\mathrm{O}$ pecado reside no seguimento da própria vontade, ou seja, no desprezo (contemptus) da vontade divina. Não se trata de destruir a própria vontade pela base, mas de não segui-la: "Da mesma maneira, pois, que se nos manda odiar a nosso pai e não matá-lo, se nos manda também não seguir nossa vontade e não destruí-la por completo ${ }^{53}$ ”.

Consentir em todas nossas vontades é pecaminoso, mas, em contrapartida, é impossível carecer totalmente delas, dado que são próprias da constituição do ser humano. Abelardo, ao concluir sua análise do exemplo exposto por seu interlocutor, afirma que pecado não é desejar uma mulher, mas consentir na concupiscência; tampouco a vontade da cópula o é, mas o consentimento da vontade é que é condenável ${ }^{54}$.

Após a análise do desejo luxurioso, Abelardo inicia uma análise do pecado da gula ${ }^{55}$. Propõe então um exemplo semelhante ao do furto das pêras narrado por Agostinho ${ }^{56}$. Supõe que alguém ao passar junto ao pomar de outro e vendo ali frutas saborosas, deseja-as, mas não consente em tal desejo. Há o desejo de saborear um fruto que poderia ser subtraído por furto ou rapina, mas não consente em tal. Onde há, porém, o desejo, aí sem dúvida está a vontade ${ }^{57}$. Embora houvesse o desejo, provocado pela fraqueza de sua natureza (suae infirmitatis natura compellitur), o agente resiste de modo a não consentir no que não convém. Reprime o desejo, mas não o extingue ${ }^{58}$.

Como observa Luscombe ${ }^{59}$, a distinção que Abelardo estabelece entre o desejo e o consentimento no desejo é um aprimoramento do pensamento deste, apresentado na Expositio Epistolae Paulinae ad Romanos, onde afirma que o pecado original cometido por Eva foi sua concupiscência.

Pretende Abelardo eliminar qualquer possibilidade de chamar a vontade de pecado, pois este está, antes, no consentimento no que não é lícito. Desse modo, alguém que estivesse pronto interiormente a fazê-lo, se

\footnotetext{
53 "Si ergo patrem odire non perimere iubemur, ita et uoluntatem nostram ut non eam sequamur, non ut funditus eam destruamus". L., p. 12, lin. 29

54 "Non itaque concupiscere mulierem sed concupiscentiae consentire peccatum est, nec uoluntas concubitus sed uoluntatis consensus dampnabilis est" L., p. 12, linha 30, p. 14, lin. 1-3.

${ }^{55}$ L., p. 14 , lin. 4.

56 AGOSTINHO, Confessionum, II 4, 9. Disponível em http://www.augustinus.it/confessionum/ index2.htm.

57 "Vbi autem desiderium ibi procul dubio uoluntas consistit". L., p, 14. lin. 09.

58 "Desiderium ille reprimit, non extinguit..." L., p. 14, lin. 14.

${ }^{59}$ L., p. 15, nota 02.
} 
fosse possível, consentiria no que é iníquo. No entanto, ainda que faltasse a possibilidade da execução, em nada diminuiria a culpa do pecado junto a Deus, pois, é igualmente réu aquele que se esforça, enquanto pode, por executar a ação iníqua, mas não a executa, quanto àquele que a executa. Há nesse ponto do texto ${ }^{60}$ uma citação nominal de Agostinho ${ }^{61}$ no que diz respeito à igualdade entre aquele, que consentindo na ação iníqua, a pratica, com aquele que consentindo, não a pratica por algum impedimento exterior. De qualquer modo, ambos são igualmente réus perante Deus, porque o pecado está no consentimento e não na execução exterior da ação.

Nas linhas que se seguem ${ }^{62}$, Abelardo afirma que há aqueles que sustentam que todo pecado é voluntário, pois distinguem entre vontade e voluntário, isto é: uma coisa é a vontade e outra aquilo a que a vontade se entrega ou no que consente ${ }^{63}$. No entanto, se pecado é o desprezo de Deus ou o consentimento naquilo que deve ser evitado por causa dele, como se pode dizer voluntário o pecado, ou seja, que se quer desprezar a Deus ou que se quer a própria ruína e, portanto, merecer a condenação? Parece impossível a Abelardo alguém querer o mal ou a condenação por si mesmos, embora aconteça de alguém, mesmo tendo consciência de que a ação deve ser punida, praticá-la; mas pratica, então, o que é iníquo, sem querer ser punido; por isso a pena é justa, mas desagrada: "desagrada a pena que é justa; agrada a ação que é injusta ${ }^{64 "}$.

Para ilustrar tal situação, o Mestre Palatino menciona que muitas vezes, seduzidos por sua beleza, queremos deitar com uma mulher, que sabemos casada. Mas, não se quer, nesse caso, cometer adultério, porque preferiríamos que ela não fosse casada. Há também aqueles que desejam as mulheres dos poderosos, justamente por vaidade, e as desejam mais porque casadas com tais homens. Há, ainda, aqueles que são arrastados pela fraqueza da carne (infirmitate carnis) ao consentimento ou à vontade má, e são constrangidos a querer aquilo que, de modo algum, quereriam querer.

Concluindo essa discussão, Abelardo afirma que este consentimento que não se quer ter, não poderá ser chamado de voluntário, a não ser que por

\footnotetext{
${ }^{60}$ L., p. 14 , lin. 19-24.

61 AGOSTINHO, De Libero Arbítrio, I.3.8. Disponível em http://www.augustinus.it/libero_arbitrio/ index2.htm

62 L., p. 16, lin. 01-06.

${ }_{63}$ LUSCOMBE, 1971, p. 16, nota 01, afirma que na Expositio III, (PL 178.894C- 895A) e na versão final da Theologia Scholarium III, (Cousin, Opera P. Abaelardi, ii 145) Abelardo escreveu que todo pecado é voluntário, ou seja, escolhido livremente; já na Ethica refina e altera sua posição.

64 "Displicet pena que iusta est, placet actio quae est iniusta". L., p. 16, lin. 15.
} 
voluntário entenda-se exclusão do necessário, uma vez que nenhum pecado é inevitável ${ }^{65}$.

Depois de Abelardo concluir a discussão sobre o pecado ser dito voluntário, o texto parece sofrer uma ruptura, pois o parágrafo seguinte inicia com a discussão sobre a indiferença moral da realização do ato pecaminoso. De fato, em dois dos manuscritos do Scito te Ipsum inicia-se um novo capítulo nesse ponto; um deles antepõe a esta seção o seguinte título: Cur exteriora meritis non addant (Por que o que é exterior nada acrescenta aos méritos) e no outro há um espaço que parece ter sido deixado pelo copista para um título que não foi introduzido ${ }^{66}$.

Nas linhas seguintes do texto aparecem afirmações de Abelardo que foram condenadas pelo Concílio de Sens (1140), dentre elas a de que alguém não se torna melhor nem pior por suas obras, ou de que a realização do pecado nada acrescenta à culpa ou à condenação junto a Deus ${ }^{67}$.

Abelardo afirma no início dessa parte do título III que "há os que se agitam, não pouco, ao ouvir-nos dizer que a realização do pecado nada acrescenta à culpa ou à condenação junto a Deus ${ }^{68}$ ". A quem Abelardo estaria se referindo? Dentre a bibliografia consultada, $\mathrm{Dal} \mathrm{Pra}^{69}$ é quem melhor possibilita uma resposta. Afirma ele que a expressão usada dá a entender que, neste caso, Abelardo está cônscio de ter contra si muitos e aguerridos adversários. O Palatino, de fato, se opõe a uma concepção objetivista da moral que, a seu tempo, era largamente compartilhada na Igreja, como é atestado pelos penitenciais, prontuários para a confissão que atentam principalmente às ações externas e que prevêem que a cada ação corresponda uma determinada pena. $\mathrm{O}$ que se pode dizer é que no concernente aos penitenciais adota-se um critério prevalentemente exterior e totalmente tarifário.

Segundo Abelardo ${ }^{70}$, esses partidários da moral objetivista vêem na ação pecaminosa certa deleitação que aumenta o pecado. Contesta Mestre Pedro afirmando que isso só seria verdadeiro se se pudesse aceitar que a deleitação carnal, por exemplo, é pecado, donde nem os cônjuges estariam

\footnotetext{
${ }^{65}$ L., p. 16 , lin. 24-30.

${ }^{66}$ LUSCOMBE, 1971, p. 16, nota letra 0.

${ }^{67}$ Cf. DAL PRA, 1976, p. 29, nota 63.

68 "Sunt qui non mediocreter moueantur cum audiant nos dicere operationem peccati nichil addere ad reatum uel ad dampationem apud deum" L., p. 16, lin. 33, p. 18, lin. 1,2.

69 DAL PRA, 1976, p. 23, nota 46.

70 L., p. 18.
} 
livres do pecado ao permitirem-se esse deleite, nem os doentes que são favorecidos com alimentos mais saborosos para convalescerem de suas doenças. Por fim, nem mesmo Deus estaria imune de culpa porque fez os alimentos com sabores, de modo que os ignorantes seriam impelidos, por sua deleitação, ao pecado.

"Ora, como se pode dizer que se comete pecado no que é permitido? Com efeito, mesmo aquelas coisas que outrora foram ilícitas e proibidas, se depois são permitidas e se tornam lícitas, já são feitas totalmente sem pecado ${ }^{71}$.”

Abelardo acrescenta ser esse o caso dos judeus, por exemplo, que convertidos a Cristo, alimentam-se de carne suína que lhes era proibida.

A fim de demonstrar a tese segundo a qual a ação externa não se identifica com o pecado, Abelardo considera primeiramente que não são pecados algumas ações que se dão conforme a natureza humana, porque conformes à vontade de Deus; depois considera o caso em que algumas dessas ações tornam-se pecado de acordo com uma proibição divina; estabelece ainda que algumas ações não são pecado pelo menos quando não há proibição divina.

Os exemplos analisados por Abelardo na Ethica são, ao menos sumariamente, situados em conjuntos de circunstâncias, de modo que se dissolve um falso absoluto, que nesse caso consistiria na objetividade de um comportamento e na dimensão interior de um ato, que são substituídos pelo movimento que os engendra: a intenção do agente moral.

Os exemplos apresentados se sucedem e servem a Abelardo para corroborar sua tese de que "não se deve adscrever ao pecado deleitação (prazer) natural alguma da carne, nem atribuir à culpa nos deleitarmos nisto, pelo que quando se dá a deleitação, é necessário que seja sentida ${ }^{72}$ ". Para

\footnotetext{
71 "Quo modo etiam in eo quod est concessum dici potest committi peccatum? Nam et illa quae quandoque illicita fuerunt atque prohibita, si postmodum concedantur et sic licita fiant, iam omnino absque peccato committuntur..." L., p. 18, lin. 18-21.

72 "... nullam naturalem carnis delectationem peccato ascribendam esse, nec culpae tribuendum in eo nos delectari, quo cum peruentum sit delectationem necesse est sentiri" L., p. 20, lin. 12-15. Para maior clareza, relembre-se que o "necesse est" ou "necessarius" neste contexto tem um significado lógicofilosófico "daquilo que não pode ser de outro modo", opondo-se ao que pode ser de um modo ou de outro.
} 
ilustrar tal afirmação é mencionado um exemplo que foi bastante criticado ${ }^{73}$ : trata-se de um religioso que obrigado a se deitar entre mulheres é compelido à deleitação ou ao prazer, não ao consentimento. "Quem presumirá chamar de culpa a essa deleitação que a natureza tornou necessária? ${ }^{74 ”}$.

O prazer físico presente em determinadas ações encontra-se na conformação natural do homem e é inseparável da própria ação. Não poderia, conseqüentemente, ser o prazer o que causa o valor moral negativo que se segue a tais ações, pois, como as ações, ele é moralmente indiferente, pois não depende do agente, acontecendo independentemente deste.

A discussão segue com outros exemplos extraídos da Escritura. À semelhança do método utilizado no Sic et Non no qual são agrupadas afirmações da Escritura e dos Santos Padres que parecem, a princípio, contradizer-se, Abelardo interpreta a passagem em que Davi ${ }^{75}$ afirma que foi concebido na iniqüidade ${ }^{76}$; não em fornicação, antes, em matrimônio. De modo que, ao afirmar que foi concebido em iniqüidade ou em pecado, referese ao pecado que é comum a todos, ou seja, ao pecado original. Tal análise é apresentada para refutar aqueles ${ }^{77}$ que insistem em afirmar que a deleitação da carne na relação sexual legítima é imputada como pecado.

São Jerônimo ${ }^{78}$ também é citado nominalmente no texto ${ }^{79}$ para ser interpretado comparativamente com uma passagem escriturística do livro de Jó (Jo 14,4-5); disto Abelardo conclui que:

"Porquanto, não tem culpa em razão do desprezo de Deus, aquele que ainda não percebe pela razão o que deve fazer; entretanto, não é imune da mácula do pecado dos primeiros

\footnotetext{
${ }^{73}$ Guilherme de S. Thierry (Disputatio, C.12, PL 180, 282AC e Epistola 326, PL 182, 532B) e S. Bernardo de Claraval (Capitula haeresum, c. 13, PL 182, 1054AB). Cf. LUSCOMBE, 1971, p. 20, nota 2.

74 "quis hanc delectacionem quam natura fecit necessariam culpam appellare presumat?". L., p. 20, lin. 18.

75 L., p. 20. lin. 20-30.

${ }_{76}^{76}$ Sl. $50,7$.

77 Segundo Dal Pra (1976, p. 26, nota 54) refletem-se nesse grupo os traços da doutrina do ascetismo monástico que remonta à mentalidade ultra-espiritual que considerava o mundo pecaminoso e entendia a moral como negação e mortificação da carne. Tal posição se firmava em Pedro Damião e, posteriormente, no pensamento de São Bernardo.

78 São Jerônimo, Commentariorum in Hiezechielem IV, cap XVI (CCL 75, p. 168, ou PL 25,130. Cf. LUSCOMBE, 1971, p. 23, nota 2.

79 L., p. 22, lin. 2.
} 
pais, de que contrai a pena, embora não a culpa, e suporta na pena o que eles cometeram na culpa ${ }^{80}$."

Também é citada uma passagem de uma das cartas de São Paulo (I Cor VII, 5), cuja interpretação conclusiva de Abelardo é a de que o Apóstolo não teria entendido indulgência (indulgentiam) como perdão dos pecados, mas como permissão para que os cônjuges declinem de uma vida mais perfeita para usufruir de uma vida mais aliviada ${ }^{81}$.

A conclusão de Abelardo para toda essa discussão é enfática:

\begin{abstract}
"Em nada, pois, concorre qualquer execução da ação para o aumento do pecado e nada mancha a alma senão o que é dela, isto é, o consentimento, que tão-só dizemos ser pecado; não a vontade que $\mathrm{o}$ precede nem a execução da ação, que $\mathrm{o}$ segue ${ }^{82}, "$
\end{abstract}

Novamente nesse ponto e de modo breve, porém incisivo, Abelardo reassume o tratamento dado anteriormente à identificação do pecado com o consentimento, não só para distingui-lo, de modo rigoroso, da voluntas como movimento espontâneo que o precede, mas também da ação subseqüente, que dele decorre, mas que nada lhe acrescenta do ponto de vista ético.

A argumentação de Abelardo prossegue, examinando casos em que é possível a ação ou a vontade sem o pecado, bem como é possível o pecado sem a vontade e sem a ação ${ }^{83}$, pois nem a vontade e nem a ação são, por si só, pecado ${ }^{84}$. Por exemplo, o que é feito por violência ou por ignorância; assim, uma mulher que é obrigada à força a dormir com um homem de outra; ou um homem que, por engano, dorme com a mulher que julga sua esposa; ou ainda, mata por erro alguém que ele acreditava, como juiz, dever

\footnotetext{
80 "Culpam quippe non habet ex contemptu Dei, qui quidem quid agere debeat nondum racione percipit, a sorde tamen peccati priorum parentum immunis non est a qua iam penam contrahit, etsi non culpam, et sustinet in pena quod illi commiserunt in culpa" L., p. 22, lin. 5-9. A doutrina ortodoxa é que a humanidade herda, não só a pena, mas também a culpa. Cf. Tomás de Aquino. Suma Teológica, $\left.\right|^{\mathrm{a}}$ Ilae, q. 81, a.1.

81 L., p. 22, lin. 20-30.

82 "Nichil ergo ad augmentum peccati pertinet qualiscumque operum executio, et nichil animam nisi quod ipsius est coinquinat, hoc est consensus quem solummodo peccatum esse diximus, non uoluntatem eum precedentem uel actionem operis subsequentem" L. p.22, lin. 32 ss, p. 24, lin. 1-2.

${ }^{83}$ L., p. 22, lin. 32-34; p. 24, lin. 01-8.

${ }^{84}$ Pode-se propor a seguinte relação dos exemplos propostos por Abelardo quanto ao tipo de ação a que se refere:
} 
matar. Se antes Abelardo denominava pecado o consentimento na vontade má, apresenta, com estes exemplos, o consentimento na ação. O pecado como tal não está nem na vontade má nem na ação e sim no consentimento.

A respeito da passagem da Escritura, que preceitua "Não desejarás ${ }^{85}$ ", Mestre Pedro a interpreta ${ }^{86}$ como se referindo ao consentimento na concupiscência, que constitui o pecado. A Escritura não proíbe desejar, pois não podemos evitá-lo e, portanto, segundo o qual não pecamos, mas proíbe consentir no desejo. Do mesmo modo deve ser entendida a passagem em que o Senhor fala que "Aquele que lançar um olhar de cobiça para uma mulher já cometeu adultério em seu coração ${ }^{87 "}$. O sentido de "lançar um olhar de cobiça" não é outro que "consentir na concupiscência".

Sem dúvida, há preceitos e proibições a respeito da ação. Para Abelardo, no entanto, a vontade e o consentimento sempre estarão em nosso poder, isto é, sob o arbítrio humano. De modo que, quando a Lei parece proibir as ações, como no caso dos preceitos bíblicos "Não matarás" e "Não dirás falso testemunho ${ }^{88 "}$ e, ainda, quando diz que não se deve casar com a própria irmã $\tilde{a}^{89}$, se estas palavras forem tomadas em sentido literal e consideradas em referência à ação, não se deve entender que eles proscrevem o delito ou proíbem a culpa. Assim, não se há de chamar transgressor quem faz o que está proibido, mas a quem consente naquilo que sabe proibido, pois o desconhecimento da proibição ou da circunstância, como no caso de alguém que desposa sua irmã sem o saber, escusa de culpa e de pecado.

Segundo Dal $\operatorname{Pra}^{90}$ o recurso a auctoritates é constante no Scito te Ipsum, pois Abelardo não só invoca a Escritura para fundamentar ou argumentar a favor de sua tese, como também invoca os Padres da Igreja. Abelardo se detém no exame das passagens bíblicas que conteriam prescrições ou proibições e procura mostrar que onde estas se relacionam ao desejo ou à ação, devem ser entendidas como se referindo ao consentimento ao desejo e ao consentimento à ação, o que o leva a concluir exatamente por que o bem e o mal se referem, propriamente, ao consensus, e não à voluntas ou a operatio.

\footnotetext{
85 Deut, V, 21.

${ }^{86}$ L., p. 24 , lin. $17-20$.

87 Mat V, 28.

${ }^{88}$ Deut $\mathrm{V}, 17,20$.

${ }^{89}$ Cf. Deut 27, 22 e Lev 20,17.

90 DAL PRA, 1976, p. 30, nota 68.
} 
Dentre os autores cristãos citados, Agostinho ocupa lugar de preeminência. É o que se observa na passagem que se acabou de examinar, pois, ao finalizar a discussão sobre o pecado e iniciar o debate sobre a intentio, Abelardo cita nominalmente uma frase do Hiponense: "Nada preceitua a lei a não ser a caridade e nada proíbe, a não ser o apetite ${ }^{91 "}$. Acresce ainda a citação de São Paulo: "Amarás teu próximo como a ti mesmo" e "A plenitude da lei é o amor" (Rom. XIII, 8,10)"

Toda a construção do pensamento ético em Abelardo parece culminar naquilo que, a partir dessas duas citações, começa a ser discutido: a doutrina da intentio.

\section{Considerações Finais}

A leitura das obras éticas de Abelardo revela uma abordagem singular da problemática ético-teológica do século XII. Igualmente se pode dizer que ela oferece uma imagem do autor que destoa de outras leituras possíveis, talvez para evidenciar os paradoxos que sempre envolveram a figura desse pensador ${ }^{93}$. Seja como for, o Abelardo que se vislumbra em suas obras éticas se apresenta como um espírito livre porque propõe a possibilidade da consciência como instância última, na qual se julga a culpabilidade ou a inocência do agente, e porque com essa postura rompe com a tradição dos penitenciais, que se prendiam à exterioridade da ação, desconsiderando, portanto, a dimensão psicológica do agente quando da execução do ato.

Desse modo, somente a intentio determina a moralidade do agente, porquanto o ato em si mesmo é moralmente indiferente. Assim, os mesmos atos podem ser praticados por bons e maus, pois o que de fato assegura a moralidade (ou a falta dela) é o modo de proceder do agente; tal é o caso, por exemplo, dos que crucificaram a Cristo.

Abelardo parece provocar, com esse exemplo, a atenção dos teólogos monásticos do século XII, pois pretende debater o fato de que os algozes como não acreditavam que Cristo era Filho de Deus e julgavam fazer o que era correto, não desprezavam a Deus e nem consentiam no mal. Portanto, a

\footnotetext{
91 "Nichil precipit lex nisi karitatem et nichil prohibet nisi cupiditatem". AGOSTINHO, De doctrina Christiana, iii, 10, n 115 (CCL 32, p. 87, ou PL 34.71) In: LUSCOMBE, 1971, p. 27, nota 3.

92 L., p. 26, lin. 27-32.

${ }_{93}$ Quanto às possíveis leituras sobre a personalidade e o pensamento de Abelardo, cf. JOLIVET, 1977, p. 307-322.
} 
ignorância, como tal, não constitui pecado, a não ser que ela seja positivamente desejada, como, por exemplo, no caso de Eva que, mesmo advertida, ignorou o preceito divino ao saborear o fruto da árvore proibida.

Numa tentativa de esquematizar a relação entre os conceitos éticos fundamentais, poder-se-ia afirmar que a intenção (intentio) refere-se ao fim (finis) que se quer atingir pelo consentimento (consensus) em uma atividade concreta (operatio). Na ordem da efetivação o consensus precede a intentio; que precede, por sua vez, a operatio. O consensus e a intentio independem da concretização da operatio. Mas na ordem lógica teríamos: intentio, consensus, operatio.

Desse modo, tem-se que o alcance da concepção ética abelardiana está no fato de apontar a moralidade como exclusiva da intenção do agente. Isso, porém, que é sua inovação é também seu limite: Mestre Pedro não se preocupou em estabelecer uma tipologia dos atos humanos, bem como não se preocupou em elaborar uma teoria da psique humana no sentido de determinar o que compete a cada esfera ou parte dessa. 


\section{Referências Bibliográficas}

\section{Obras de Pedro Abelardo:}

ABELARDO. Petri Abaelardi Commentariorum super S. Pauli epistolam ad romanos. J.P. MIGNE. Patrologiae Cursus Completus, Series Latina; tomus CLXXVIII. Parisiis, 1885, col. 783-978.

ABELARDO. Petri Abaelardi Dialogus Inter Philosophum, Iudaeum Et Christianum. J. P. MIGNE. Patrologiae Cursus Completus, Series latina, tomus CLXXVIII. Parisiis, 1885, col. 1609 - 1684D.

ABELARDO. Petri Abaelardi Ethica seu Líber dictus Scito Te Ipsum. J. P. MIGNE. Patrologiae Cursus Completus, Series latina, Tomus CLXXVIII. Parisiis, 1885, col. 633-678.

ABELARDO, P. Die Logica Ingredientibus. In: Peter Abaelard, Philosophische Schriften, zum ersten Male herausgegeben von Dr. Bernhard Geyer, Beitrage zur Geschichte der Philosophie des Mittelalters. Münster i. w., 1919, 1921, 1927; XII (1-3): 1-503

ABELARDO. Sic et Non. A Critical Edition. Chicago, 1976. Tradução para a língua inglesa de B.B. Boyer e R. McKeon (ed.) Traduzido para a língua portuguesa por Luís Alberto de Boni. Filosofia Medieval: textos. Porto Alegre: EDIPUCRS, 2000.

ABELARDO. Ethical Writings: His Ethics or "Know Yourself" and His Dialogue between a Philosopher, a Jew and a Christian. Translated by Paul Vincent Spade, with an Introduction by Marilyn McCord Adams. Indianapolis/Cambridge, Hackett Publishing Company, Inc, 1995.

ABELARDO. Diálogo entre un filósofo, un judío y un cristiano. Biblioteca de Obras Maestras del Pensamiento 30. Estudio preliminar, traducción y notas de Silvia Magnavacca. Edición Bilingüe. Buenos Aires: Editorial Losada, 2003.

Outras obras citadas:

AUbEnQUE, P. A Prudência em Aristóteles. Tradução de Marisa Lopes. São Paulo: Discurso Editorial, 2003. 
AGOSTINHO. Confissões. Tradução de J. Oliveira Santos, S.J. e A. Ambrósio de Pina, S. J. Coleção Os Pensadores. São Paulo: Nova Cutural, 1996.

AGOSTINHO. O Sermão da Montanha. São Paulo: Paulinas, 1992.

AGOSTINHO. De Libero Arbitrio. S. Aurelii Augustini, Opera Omnia. Editio latina; PL tomo XXXII. Disponível em: http:// www.augustinus.it/latino/libero_arbitrio/index2.htm

ADAMS, M. M. "Introduction". In: Abelard. Ethical Writings: His Ethics or "Know Yourself" and His Dialogue between a Philosopher, a Jew and a Christian. Translated by Paul Vincent Spade, with an Introduction by Marilyn McCord Adams. Indianapolis/Cambridge, Hackett Publishing Company, Inc, 1995.

BLOMME, R. "A propos de la définition du péché chez Abélard”. Ephemerides Theologicae Louvanienses, XXXIII, 1957, pp. 319-47.

. La doctrine du péché das les écoles théologiques de la premiére moitié du XIIe siècle. Louvain/Gembloux, 1958. Universitas catholica Lovaniensis.

DAL PRA, M. "Introduzione". In: ABELARDO, Pietro. Conosci te stesso o Etica. Introduzione, traduzione e note di Mario Dal Pra. La Nuova Italia Editrice: Firenze, 1976.

DIHLE, A. The Theory of Will in Classical Antiquity. California: University of California Press, 1982.

HAMELIN, G. "A lógica como veículo da ética aristotélica em Pedro Abelardo". Cadernos de História e Filosofia da Ciência. Centro de Lógica, Epistemologia e História da Ciência da Universidade de Campinas. Série 3, v. 7, nª 2, jul-dez. 1997, p. 179-208.

"L'influence d'Aristote et de Ciceron chez Pierre Abelard: le cas de la théorie de la vertu dans le Dialogus”. In: DE BONI, L. A. \& PICH, R. H. (organizadores). A Recepção do pensamento greco-romano, árabe e judaico pelo Ocidente Medieval. Porto Alegre: EDIPUCRS, 2004, p. 219-231.

LOTTIN, O. "L'intention morale de Pierre Abélard à saint Thomas d'Aquin". In: LOTTIN, Odon. Psychologie et morale au XIIe et XIIIe siècles. Gembloux: J. Duculot, 1954, Tomo IV (1), p. 309-486. 
MANN, W. E. "Ethics”. In: BROWER, J. E. e GUILFOY, K. (Eds.) The Cambridge Companion to Abelard. Cambridge: Cambridge University Press, 2004, p. 279-304.

MARENBON, J. "Life, milieu, and intellectual contexts". In: BROWER, J. E. e GUILFOY, K. (Eds.) The Cambridge Companion to Abelard. Cambridge: Cambridge University Press, 2004, p. 13-44.

. The Philosophy of Peter Abelard. Cambridge: Cambridge University Press, 1997

TOMÁS DE AQUINO. Suma Teológica. Tradução de Aimon-Marie Roguet et all. São Paulo: Edições Loyola, 2001, v. III.

E-mail: pedrofernandes28@hotmail.com

Recebido: maio/2009

Aprovado: julho/2009 